Article

\title{
Development of STEM Instructional Resources for Teaching Optics to Teachers-in-Training: Influence on Learning and Teacher Self-Efficacy
}

\author{
Guadalupe Martínez-Borreguero*(D), Francisco Luis Naranjo-Correa (D) and Milagros Mateos-Núñez
}

check for

updates

Citation: Martínez-Borreguero, G.;

Naranjo-Correa, F.L.; Mateos-Núñez, M. Development of STEM

Instructional Resources for Teaching

Optics to Teachers-in-Training:

Influence on Learning and Teacher

Self-Efficacy. Educ. Sci. 2022, 12, 186.

https://doi.org/10.3390/

educsci12030186

Academic Editor: Stanislav Avsec

Received: 15 February 2022

Accepted: 4 March 2022

Published: 7 March 2022

Publisher's Note: MDPI stays neutral with regard to jurisdictional claims in published maps and institutional affiliations.

Copyright: (C) 2022 by the authors. Licensee MDPI, Basel, Switzerland. This article is an open access article distributed under the terms and conditions of the Creative Commons Attribution (CC BY) license (https:/ / creativecommons.org/licenses/by/ $4.0 /)$.
Department of Science Teaching, Universidad de Extremadura, 06006 Badajoz, Spain; naranjo@unex.es (F.L.N.-C.); milagrosmateos@unex.es (M.M.-N.)

* Correspondence: mmarbor@unex.es

\begin{abstract}
Studies related to teacher training in primary education indicate a lack of knowledge, low levels of teaching self-efficacy, and negative emotions towards the teaching of physics. The main objective of this research was to compare the influence of two teaching methodologies on the learning and teaching self-efficacy of teachers-in-training on optics content related to light and color. The research design was quasi-experimental with control and experimental groups, a pre-test, and two post-tests. A non-probabilistic sample of 173 trainee primary school teachers was used. The control group used an academic-expositional teaching methodology, and the experimental group used a practical methodology based on the use of STEM teaching tools. Measuring instruments were designed and applied before and after the interventions to measure the evolution of cognitive and competence variables of the participating sample, depending on the methodology applied, both in the short and long term. The results reveal statistically significant improvements between the control group and the experimental group, both in the knowledge level variable and in the teaching self-efficacy variable.
\end{abstract}

Keywords: physics; optics; teachers-in-training; STEM education; knowledge; self-efficacy

\section{Introduction}

\subsection{Cognitive and Affective Aspects in Teacher Training}

Currently, the lack of scientific and technological vocations among pupils is becoming increasingly apparent, as pointed out in various European reports [1,2]. Numerous studies have found that primary school pupils tend to show interest, enthusiasm, and generally positive attitudes towards science, but that these attitudes diminish with age, especially during secondary school [3-5] and particularly towards subjects such as physics and chemistry [6-8]. This progressive lack of interest among adolescents is leading them away from school science so that the natural consequence is the abandonment of scientific pathways in their first choice of studies, a result that is currently a cause for concern [9].

Taking this into account, the professionalism of teachers is always in the spotlight when discussing educational quality [10]. The teacher, as a counsellor, must be able to design learning situations that encourage the autonomous and responsible construction of knowledge, values, and professional skills in students in an environment of participation and dialogue [11]. However, there are many reports from international organizations showing the global need to improve teacher training [12-14]. Previous studies [15] have shown that in addition to poor knowledge of science, teachers-in-training have low levels of teaching self-efficacy and negative emotions and attitudes towards these subjects, which are generally related to the difficulties they have in learning scientific content [16]. Specifically, several authors have shown that future primary school teachers have a low level of knowledge and negative emotions toward science $[17,18]$. This is a problem for the current education system, as this group must teach their future primary school pupils scientific 
content that they themselves have not mastered. This generates stress, anxiety, and low levels of teaching self-efficacy, and teachers recognize that they do not feel prepared to teach science subjects $[19,20]$. Other studies add that this group also feels reluctant to teach science content or may even show anxiety about teaching these concepts [21,22]. In addition, research analyzing the teaching of primary school teachers $[23,24]$ indicates that they have low levels of self-efficacy beliefs and low confidence in teaching science. Other studies add that little time is used for teaching science topics in the classroom [25] or that more traditional and expository methodologies are used [26,27], which has an impact on the attitudes and learning of primary school pupils $[5,26,28,29]$. Therefore, it is considered necessary to pay more attention to the science education of trainee teachers so that they can improve pupils' learning and interest in science at school in their future careers [28,30,31]. There is a need for teachers who are enthusiastic about science teaching [32].

\subsection{Misconceptions in Physics}

In addition, studies in physics education point to the existence of misconceptions among students at all levels of education, from kindergarten to university [33]. Furthermore, physics is often identified as the subject that arouses the least interest in students in general and in female students in particular [34]. They perceive the subject of physics as something abstract, complicated, difficult, and incomprehensible. There are studies that indicate the presence of misconceptions about physics content not only among primary and secondary school students but also among future teachers of these levels [35-39]. All these studies have revealed that, at all levels of education, students have difficulties in learning optics [38]. Other studies have shown in cross-curricular research that a large percentage of students at all educational levels has similar misconceptions about the concept of light, from primary school to college [39]. Focusing on the university students, some authors [40,41] have revealed the difficulties in teaching/learning and conceptual errors in optics presented by trainee teachers. The results of some studies have shown that primary school teachersin-training have serious difficulties in articulating coherent explanations of basic ideas about the concept of light [42]. For example, some authors examined university students' understanding of images formed with plane mirrors and with converging lenses and concave mirrors, concluding that this group presents various difficulties in understanding this content [43]. Others studied the conceptions of future primary school teachers about pinhole patterns and shadows $[44,45]$. On this basis, the persistence of these misconceptions in trainee teachers, both at the primary and secondary levels, is of particular concern. Variables such as the level of knowledge of future teachers, their interests, attitudes, and the activities they carry out in the classroom have a great influence on student learning [46].

\subsection{Teacher Self-Efficacy and Implications for Teaching Processes}

In general, science teachers are concerned about their ability to apply a novel teaching method and about the adequacy of their own professional training in science content and teaching. This is especially true for primary school teachers who often lack content knowledge in different areas of science, which makes them feel insecure and not competent in these areas $[19,20,32,47]$. These studies indicate that the lack of competence related to low science knowledge causes insecurity and anxiety for teachers [48]. Other authors indicate that these low levels of confidence in science teaching, as well as low levels of ability to teach science, are closely related to teaching self-efficacy [49]. Self-efficacy is defined as the belief that one can successfully perform a particular task to produce certain results or achieve certain goals [50]. To achieve the best possible academic results for their students, teachers must perceive themselves as competent and prepared in their subjects. Teachers' self-efficacy beliefs play an important role in their teaching, and may influence their choice of classroom activities or even their professional practice [50]. Specifically, from the point of view of science teaching at early levels of education, some authors indicate that teachers with higher levels of self-efficacy tend to incorporate more effective and student-centered teaching practices, promoting meaningful learning [51]. However, 
those with low levels of self-efficacy tend to rely more on traditional teaching and follow textbooks, limiting students' creativity in understanding science concepts [52]. Thus, the acquisition of scientific knowledge by teachers is a necessary but not sufficient condition, i.e., it does not automatically guarantee its transfer to classroom practice [17]. In fact, there are four central components to be adopted by teachers, namely theoretical knowledge, knowledge of students' misconceptions, curricular knowledge, and knowledge of teaching strategies [53]. Bearing in mind that teacher education must be a continuous, flexible, and contextualized educational process, it is essential that education professionals receive, in turn, innovative and up-to-date training [54]. In this sense, it will be necessary to provide future teachers with adequate didactic materials that allow them to reflect in class on the main aspects of the nature of science and through which they can integrate in a single structure the knowledge of the subject to be taught $[11,17]$.

Therefore, in the current educational context, teachers must deploy new skills and ways of approaching educational strategies that have a positive impact on the teaching-learning process [55]. The importance of using everyday references in the teaching of science, and specifically physics, is emphasized by the negative attitudes that students have towards this subject and which have an adverse influence on academic performance [56]. International authors and organizations have proposed methodologies and strategies to increase the achievement and motivation of students at the basic level, always emphasizing the use of experimental resources and experimentation in the instruction of physics [57,58]. Practical experiences are necessary for students to realize that physics is a natural science [59] and that every theory must be based on the answers that nature provides to questions adequately formulated by means of experiments. Many researchers have examined the positive contributions of using inquiry activities or experiments in lessons for learning physics [60]. Some authors highlighted a model of professional development for secondary school science teachers according to guided inquiry [61]. Their results showed that professional development activities helped teachers to design more guided inquiry-based teaching units and to better understand the benefits of inquiry. On the other hand, results from other studies support the relationship between the use of the inquiry method and increased confidence in science teaching in primary school teachers [47]. Furthermore, the implementation of inquiry during the training of prospective primary school teachers improved their personal beliefs about their self-efficacy in teaching science [62].

\subsection{New Approaches to Education: STEM Education}

In the light of the above, the most appropriate educational model for science learning must contrast with the mere reception of knowledge by learners [63] and must be based on the idea that the teacher has an important mediating role between the learner and the knowledge. That is, the teacher provides appropriate scaffolding, and the learners are active constructors of their own knowledge [64]. In this sense, it is assumed that initial science teacher education should promote situations that invite self and shared reflection on essential aspects of science education [65]. This is where a new educational paradigm known as STEM (Science, Technology, Engineering, and Mathematics) education comes into play, which integrates all scientific disciplines [66]. The fragmentation of knowledge imposed by the separation of subjects is generally accepted [10], but several authors indicate that promoting an integrated science curriculum $[67,68]$ is one of the keys to connecting the content with the world and, therefore, with the reality of the students themselves [69]. Several studies point out that integrative approaches provide students with a rich learning context to enhance students' learning and interest in STEM fields [70], which may enhance motivation in their future careers [71]. However, integrating interdisciplinary projects into the curricula at different educational levels is complicated when teachers lack the necessary knowledge to deal with such projects effectively [72]. A successful change in curriculum approach must start with well-trained and willing teachers [73]. In this sense, continuous training in didactics and scientific knowledge, professional development and 
experiences, and time for discussion with peers will enable teachers to improve not only teaching practice but also the quality of students' education [72].

All this background is relevant from a didactic point of view, as it highlights the need to develop and implement methodologies in the classroom that enhance the acquisition of scientific and didactic competence of the trainee teacher to improve the teaching of these contents to future primary school students. For this reason, in this research, several STEM teaching tools based on hyper-realistic simulations [74-78] were designed to improve the teaching-learning of optics for future teachers with the aim of combating the misconceptions of this group and improving their scientific-didactic component. Specifically, the concepts of light and color were selected because, although they are introduced in the education curriculum from the early stages of school, there are many misconceptions and conceptual errors about them that persist up to higher levels of education [79].

\section{Materials and Methods}

The research design was quasi-experimental and of a quantitative nature, with a pretest and two post-tests, a control group, and an experimental group. Both descriptive and inferential data analyses were carried out. Likewise, didactic materials were developed to help prospective teachers in their professional future to design teaching/learning sequences with scientific-didactic rigor.

\subsection{Objectives}

The main objective of the study was to compare the influence of two teaching methodologies on the learning and teaching self-efficacy of the trainee teachers for physics content related to light and color. To achieve this objective, didactic interventions based on STEM practices and hyper-realistic simulations were designed, implemented, and compared with an expository academic teaching of the same concepts.

The general objective was broken down into the following specific objectives:

- Specific Objective 1 (SO1): To validate from a didactic point of view the usefulness of the didactic tools developed for the learning of the selected optics contents.

- $\quad$ Specific Objective 2 (SO2): To verify whether the concepts of light and color learned by the trainee teachers through different teaching methodologies last or are forgotten with the passage of time.

- $\quad$ Specific Objective 3 (SO3): To test whether levels of teacher self-efficacy improve as a function of the teaching methodologies applied with trainee teachers.

\subsection{Hypotheses}

Based on the proposed objectives, the following study hypotheses were proposed:

Hypothesis 1 (H1). Students who use hyper-realistic simulations and STEM experiences to learn basic optics concepts related to light and color have similar average initial scores to students who follow an academic-expositional teaching intervention.

Hypothesis 2 (H2). There are no statistically significant differences in the short-term knowledge level variable of students who follow a didactic intervention based on the use of hyper-realistic simulations and STEM experiences compared to students who follow an academic-expositional didactic intervention.

Hypothesis 3 (H3). There are statistically significant differences in the long-term learning variable between students in the experimental group using STEM simulations and experiences and students in the control group following an academic-expositional teaching intervention.

Hypothesis 4 (H4). Hyper-realistic simulations and STEM experiences on light and color facilitate meaningful, long-term learning for trainee primary school teachers. 
Hypothesis 5 (H5). The development and implementation of didactic interventions on basic concepts of optics related to light and color produce a positive evolution in the variable level of teaching self-efficacy in trainee teachers.

\subsection{Sample}

The sample, chosen by non-probabilistic convenience sampling due to the ease of access (as they were the students we teach) consisted of 173 primary school teachers-intraining. The participating subjects were studying experimental science didactics to become future teachers. In this subject, they were taught the scientific and didactic content for teaching/learning the concepts of the subject of natural sciences at the primary school stage so that they could explain them to their future pupils in a meaningful way. The students were divided into two homogeneous and equivalent groups in terms of initial knowledge level, a control group, and an experimental group to test the research hypotheses. Table 1 shows the descriptive analysis of the sample according to group and gender.

Table 1. Descriptive analysis of the sample.

\begin{tabular}{cccccc}
\hline Degree & Group & Gender & Percentage & Frequency & Total \\
\hline \multirow{3}{*}{$\begin{array}{c}\text { Degree in Primary } \\
\text { Education }\end{array}$} & \multirow{2}{*}{ Control } & Male & $27.9 \%$ & 24 & 86 \\
& \multirow{2}{*}{ Experimental } & Female & $72.1 \%$ & 62 & 28 \\
& & Male & $32.2 \%$ & 59 & 87 \\
\hline
\end{tabular}

As shown in Table 1, the first group, called the Control Group (CG), consisted of 86 subjects. The second group, called the Experimental Group (EG), consisted of 87 students. These groups were made up of students from the degree of primary education, future primary education teachers. The absolute frequency and percentage of the variable gender are indicated. In the control group, $72.1 \%$ were female and in the experimental group approximately $67.8 \%$ were female. The age range of the participants was 20 to 26 years. Both the control group and the experimental group used the same amount of time to teach the contents. The didactic methodology of the control group was based on a more traditional teaching, using different presentations and theoretical explanations of the selected contents as learning resources. However, with the experimental group, practical sessions were carried out based on STEM experiences [80] and the use of hyper-realistic simulations of our own elaboration [74,76,77]. For the development and implementation of the simulations, we used software specifically designed for rendering photorealistic graphical environments, namely POV-Ray, an open-source ray tracer [81]. The choice of this program was motivated by the need for a technique capable of faithfully imitating the optical system in a way that was consistent with the theoretical models involved. POV-Ray uses a ray tracing technique based on geometrical optics that simulates images with great realism [82-84]. The software models the path of light following rays as they interact with optical surfaces, resulting in accurate simulations of optical phenomena. These simulations arise as a natural result of the combined use of the ray-tracing algorithm and a specific Monte Carlo algorithm for the synthesis of three-dimensional images with perspective. These hyper-realistic simulations show environments of optical phenomena that reproduce the behavior of real systems with a higher level of reality than traditional computer simulations. The STEM experiences are practical projects carried out by the students using easily available materials. In the experience, the didactics of the selected science, technology, engineering, and mathematics contents are explained to the students in an interrelated way. An observation sheet is also included, containing questions that focus the students' attention on the contents being worked on. In addition, a guide is added where the didactic and methodological components of each experience are specified so that they can be easily carried out in any school. By way of example, Figure 1 shows some of 
the simulations used with the experimental group. The simulation of a flat diopter, a coin immersed in water, a convergent lens, chromatic aberration, a prism, a concave mirror, and the same horse under two different illuminants is presented.

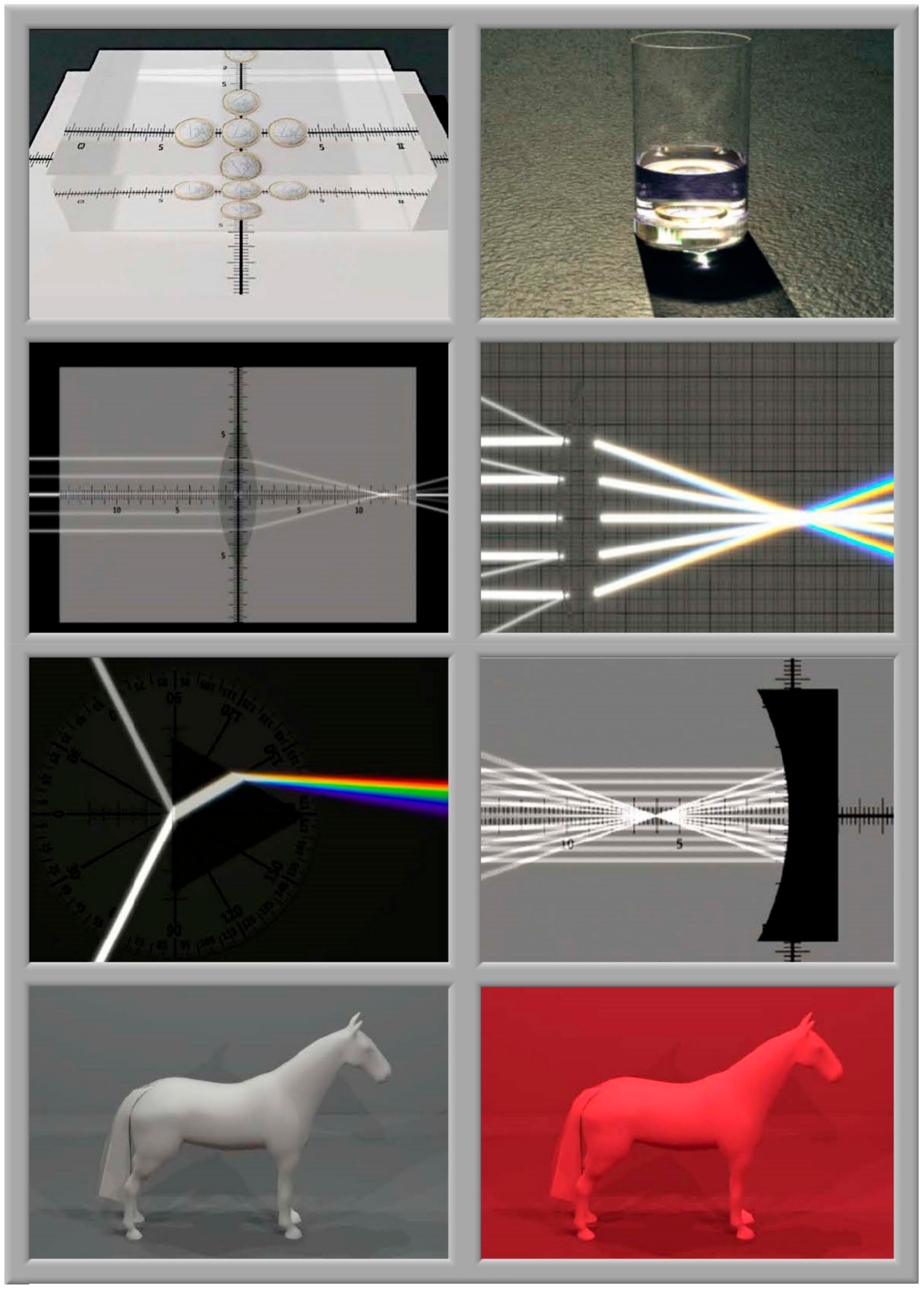

Figure 1. Examples of hyper-realistic simulations used in the EG. 


\subsection{Measuring Instrument}

Two measurement instruments were designed based on the variables under study: one to measure the variable level of knowledge and the other to measure the variable level of teaching self-efficacy. Each of them is described below, followed by the validation of each of these instruments.

First, a test was designed to detect misconceptions about basic concepts of optics related to light and color. The test consisted of 35 closed multiple choice questions with a single answer, based on previous studies $[79,85]$ and designed considering the distractor theory and the scientific literature on misconceptions in optics. These questions could be grouped into several categories according to the specific concepts worked on. Specifically, they were grouped into four categories:

Category I aimed to analyze whether the learner remembered basic concepts about what light is and its nature, behavior, and characteristics and was called Category I- Light. Nature and Propagation.

Category II aimed to identify whether students could distinguish between light primary colors, ink primary colors, additive mixing, subtractive mixing, and the perception of the color of objects as a function of the illuminant used. This category was labelled Category II-Color.

The purpose of category III was to analyze whether students had preconceptions about the laws of reflection and refraction of light; the formation of images in a mirror; and the behavior of lenses, prisms, or filters, among other optical systems. This category was called Category III-Simple Optical Systems (laws of geometrical optics).

Category IV aimed to find out if students knew how rainbows are formed and their nature and was named Category IV-Rainbows.

As examples, some of the questions included in the questionnaires designed are shown in Table 2.

Table 2. Sample questions from the designed tests.

Which if the options below describe the behavior of a lens?

A wall looks white in daylight. What color will the wall look if you illuminate it simultaneously with a green light and a red light at night?
(a) It refracts light
(b) It always makes an object look bigger
(c) It always makes an object look smaller
(d) All options are valid
(a) Black
(b) Green
(c) Yellow
(d) Red

In the formation of the rainbow, when the light reaches a raindrop ... (a) It is refracted when it enters the drop, it is reflected in the interior, and it is again refracted when it leaves the drop.

(b) It is reflected when it enters the drop, it is refracted in the interior, and is reflected again when it leaves the drop.

(c) It is refracted when it enters the drop, and it is reflected when it leaves the drop.

(d) It is reflected when it enters the drop, and it is refracted when it leaves the drop.

The misconception detection test was used with the students at three different times, specifically once as a pre-test and twice as a post-test. The pre-test was given at the beginning of the didactic sessions before the teaching of the contents under study in the two groups began. The aim of post-test I was to check the effectiveness of the didactic methodology used in each group, as well as to check the persistence of the misconceptions after carrying out different teaching-learning sequences. Specifically, the students were 
tested after their respective teaching sessions (control and experimental) to find out the degree of acquisition of the contents explained according to the different didactic resources used in the sessions. The purpose of post-test II was to verify whether significant learning had taken place in the students and whether they remembered the content explained after the passage of time. The students in both groups were tested months after post-test I.

In addition, the aim was to analyze the level of self-efficacy of prospective primary school teachers in teaching content about light and color. For this purpose, a questionnaire was designed based on previous research $[15,86,87]$. The questionnaire, on teaching selfefficacy on light and color, consisted of 28 items that were formulated based on the optical contents and activities to be developed in the classroom of the fifth and sixth grades of primary education. The trainee teachers had to rate on a 4-point Likert scale (0: Not at all competent, 1: Not very competent, 2: Fairly competent, 3: Fully competent) their level of teaching self-efficacy for the teaching of the selected light and color contents. This questionnaire was implemented before and after the didactic intervention to assess the evolution of the variable teaching self-efficacy. By way of example, Table 3 shows the statements proposed.

Table 3. Teaching self-efficacy questionnaire.

\begin{tabular}{|c|c|}
\hline Number & Statements \\
\hline I1. & Explain the phenomenon of the reflection of light. \\
\hline I2. & Explain the phenomenon of the refraction of light. \\
\hline I3. & State the laws of reflection and refraction and differentiate between them. \\
\hline I4. & $\begin{array}{l}\text { Give examples from everyday life involving the phenomena of reflection } \\
\text { and/or refraction. }\end{array}$ \\
\hline I5. & Explain why putting a pencil in a glass of water makes it look broken. \\
\hline I6. & Explain why we see objects in certain colors. \\
\hline I7. & Explain the concept of primary and secondary colors. \\
\hline I8. & Differentiate between additive and subtractive color mixing. \\
\hline I9. & Explain how rainbows form. \\
\hline I10. & Explain what light scattering is and give an example. \\
\hline I11. & Carry out a practical exercise in the laboratory to simulate a rainbow. \\
\hline I12. & Explain why the sky is blue. \\
\hline I13. & Explain how light propagates, in what kind of media, and at what speed. \\
\hline I14. & Define and explain the behavior of a converging lens. \\
\hline I15. & Define and explain the behavior of a diverging lens. \\
\hline I16. & Give examples of everyday instruments or devices that use lenses. \\
\hline I17. & $\begin{array}{c}\text { Explain what type of lens can be used to correct myopia, hyperopia, or } \\
\text { astigmatism. }\end{array}$ \\
\hline I18. & Differentiate between opaque, translucent, and transparent materials. \\
\hline I19. & Give examples of opaque, translucent, and transparent materials. \\
\hline $\mathrm{I} 20$. & Explain the formation of images in a plane mirror. \\
\hline I21. & $\begin{array}{l}\text { Distinguish the type of image formed in a plane mirror from that formed in a } \\
\text { concave or convex mirror. }\end{array}$ \\
\hline $\mathrm{I} 22$. & Plan a didactic unit to explain the concepts related to light and color. \\
\hline I23. & $\begin{array}{c}\text { Develop an innovative didactic intervention in the classroom to explain all } \\
\text { these concepts. }\end{array}$ \\
\hline I24. & Propose activities to assess students' acquisition of these contents. \\
\hline I 25. & Use simulations in the classroom to help students understand this content. \\
\hline I26. & $\begin{array}{c}\text { Design and develop a computer simulation to help students understand } \\
\text { these concepts. }\end{array}$ \\
\hline I27. & $\begin{array}{l}\text { Develop a concept map to explain to students the differences and } \\
\text { applications of the concepts related to light and color. }\end{array}$ \\
\hline I28. & $\begin{array}{l}\text { Perform a recreational physics exercise to explain these concepts to the } \\
\text { students. }\end{array}$ \\
\hline
\end{tabular}




\subsection{Validation of the Evaluation Instrument: Calibration Indices of the Misconceptions Test}

Firstly, the results referring to the validity and reliability of the misconceptions test used in the research are presented based on the analyses recommended by other studies [88-90]. Based on the results obtained, we can affirm that the test for the detection of misconceptions designed presents an adequate degree of reliability and validity, constituting a reliable assessment instrument with an adequate level of difficulty and discriminatory power, as we will see below.

Specifically, the validity and reliability of this measurement instrument was determined through the consensus of opinions of a group of experts. Following the guidelines set by some previous studies [88], a concordance test was carried out among experts, who were provided with eight assessment criteria on which they had to mark their degree of agreement (scored as 1) or disagreement (scored as 0 ). The degree of agreement is calculated as the result of the number of total agreements divided by the sum of the number of total agreements plus the total disagreements. The value obtained in this evaluation was 0.91 , which indicates a degree of agreement classifiable as very good according to the literature [88].

In addition, several psychometric tests were carried out following the methodology recommended by other authors [89-92]. Statistical tests focused on the assessment of the test items, such as the difficulty index, discrimination indices, point biserial coefficient, Ferguson's Delta, and Kuder-Richardson's 20 coefficient, were performed using the methodologies specified in previous studies. As shown in Table 4, all values are within the recommended range.

Table 4. Psychometric analysis of the evaluation instrument.

\begin{tabular}{ccc}
\hline Coefficient & Obtained Value & Recommended Value \\
\hline Mean difficulty index (P) & 0.49 & {$[0.30-0.90]$} \\
Mean discrimination index 1 (D1) & 0.36 & $\geq 0.30$ \\
Mean discrimination index 2 (D2) & 0.72 & $\geq 0.50$ \\
Mean point biserial coefficient & 0.32 & $\geq 0.20$ \\
$\left(\mathrm{r}_{\text {pb }}\right)$ & 0.91 & $\geq 0.90$ \\
Ferguson's Delta $(\delta)$ & 0.72 & $\geq 0.60$ \\
KR-20 & & \\
\hline
\end{tabular}

The mean difficulty index $(\mathrm{P})$ of the test indicates the degree of difficulty of the test so that the higher the index, the easier the question asked. The calculation of this index was carried out for all the questions that made up the test, obtaining similar difficulty values for all of them, which were within the established ranges. Table 4 shows that an average value of $p=0.49$ was obtained, so in general, the degree of conceptual difficulty of the instrument is adequate for the research.

Subsequently, discrimination indices were calculated. Discrimination index 1 (D1) measures the discriminatory power of each item in a test, i.e., it allows us to conclude whether the test can distinguish those subjects with stronger knowledge who answer correctly from those subjects whose understanding is weaker. Discrimination index 1 (D1) was calculated for all questions included in the instrument to check whether there were questions that were excessively easy or excessively difficult that did not discriminate and therefore did not contribute to the reliability of the instrument. The average value obtained in the test, as specified in Table 4 , is D1 $=0.36$, indicating an adequate discrimination index. Discrimination index 2 (D2) indicates the extent to which a question helps to distinguish between those who know the most and those who know the least, regardless of the easiness of the question, and can be considered satisfactory if it is at least higher than 0.50 , that is, if more than half of the respondents belong to the group that knows the most. In our case, this fact was fulfilled in all the questions, with an average value of D2 $=0.72$. This value is considered adequate by the literature. 
The point biserial coefficient $\left(\mathrm{r}_{\mathrm{pb}}\right)$ reflects the correlation between subjects' scores on one item with their scores on the whole test. As shown in Table 4, the average point biserial coefficient of the test is $\mathrm{r}_{\mathrm{pb}}=0.32$, so it also meets the recommended criterion.

For more evidence, we obtained Ferguson's Delta $(\delta)$. The literature recommends following the criterion that a test that offers good discriminatory power obtains a value greater than 0.90 . The tests in the study have an index of approximately $\delta=0.91$, so in general terms, the instruments offer good discriminatory power.

Finally, the Kuder-Richardson 20 coefficient (KR-20), which is a measure of internal consistency reliability for measures with dichotomous choices, was calculated. A KR-20 value of 0.72 was obtained for the misconceptions test, indicating high reliability.

\subsection{Validation of the Self-Efficacy Instrument: Calibration Indices}

To validate the self-efficacy test designed, the reliability coefficient was calculated using Cronbach's alpha to estimate the reliability of the instrument for measuring teacher self-efficacy. As pointed out by some authors [93], the measurement of reliability for items formulated in Likert-type scales assumes that the items measure the same construct and that they are correlated. Thus, if the alpha value obtained is close to 1 , the consistency of the items is excellent. On the other hand, the literature recommends obtaining the reliability of the scale with data from each sample. The result obtained was $\alpha=0.967$ for the 28 items that made up the questionnaire. This result allows us to conclude that the questionnaire for measuring the level of teacher self-efficacy has excellent reliability [94].

\section{Results}

The results obtained in the research are presented below. Firstly, the descriptive results obtained for the level of knowledge variable are shown. Subsequently, the data on the level of teaching self-efficacy expressed by the participant sample are presented. IBM SPSS Statistics 20.0 software was used for the statistical tests. In the case of the inferential comparison between the study groups (control and experimental), a Student's t-test for independent samples was used after previously verifying the Kolmogorov-Smirnov (K-S) test to check the normality of the sample, Levene's test to check the homogeneity of variances, and the runs test to check the randomness of the sample, considering in all cases a significance level of $\alpha=0.05$.

\subsection{Level of Knowledge Variable}

The results obtained in the pre-test carried out prior to the interventions are presented. Regarding the degree of prior knowledge about optics of the future teacher, it should be noted that there is a generalized and very marked lack of knowledge of basic issues. Specifically, Table 5 presents the descriptive statistics of the average scores obtained in the pre-test by each group: control (CG) and experimental (EG).

Table 5. Descriptive statistics of the average pre-test scores (CG vs. EG).

\begin{tabular}{ccccc}
\hline Group & N & Mean & Std. Deviation & Std. Error Mean \\
\hline Control Group & 86 & 4.64 & 0.994 & 0.107 \\
$\begin{array}{c}\text { Experimental } \\
\text { Group }\end{array}$ & 87 & 4.43 & 0.953 & 0.102 \\
\hline
\end{tabular}

Table 5 shows that the control group achieves an average score of 4.44 points out of 10 , with a standard deviation of 0.99 and a standard error of the mean of 0.107 . On the other hand, the students in the experimental group obtain an average of 4.43 points, with a standard deviation of 0.95 and a standard error of the mean of 0.102 . These data confirm that both groups have similar and low average scores, which coincides with previous studies that confirm the existence of misconceptions in relation to the contents of optics $[40,95,96]$.

To check for statistically significant differences between groups in the results obtained in the pre-test, an inferential analysis was carried out with a Student's t-test for equality of 
means. The normality of the distributions was previously checked, the results of which indicated that we may assume the normality of the distribution of the scores. Table 6 shows the results of the Student's t-test for independent samples.

Table 6. Student's $t$-test for independent samples of pre-test (GC vs. GE).

\begin{tabular}{cccccccc}
\hline & $\mathbf{t}$ & df & $\begin{array}{c}\text { Sig. } \\
\text { (Two-tailed) }\end{array}$ & $\begin{array}{c}\text { Mean } \\
\text { Difference }\end{array}$ & $\begin{array}{c}\text { Std. Error } \\
\text { Difference }\end{array}$ & $\begin{array}{c}\text { 95\% Confidence Interval of } \\
\text { the Difference }\end{array}$ \\
\hline Pre-test & 1.424 & 171 & 0.156 & 0.21098 & 0.14812 & -0.08140 & 0.50336 \\
\hline
\end{tabular}

As can be seen in Table 6, there are no statistically significant differences (Sig. $=0.156$ ) between the control group and the experimental group in the results obtained in the pre-test, the mean difference found being 0.21 points out of 10 . Moreover, in the analysis of each question of the questionnaire, a percentage of analogous misconceptions was observed in both groups, so we can affirm that the initial starting knowledge was equivalent for the control and experimental groups.

The results obtained in post-test I in each working group, control and experimental, are shown below. This post-test was presented to the students after the teaching of the selected contents with each of the methodologies in each group. Table 7 presents the descriptive statistics for the control group and the experimental group in post-test I.

Table 7. Descriptive statistics of the average scores on post-test I (CG vs. EG).

\begin{tabular}{ccccc}
\hline Group & N & Mean & Std. Deviation & Std. Error Mean \\
\hline Control Group & 86 & 6.94 & 1.907 & 0.205 \\
Experimental & 87 & 7.00 & 1.551 & 0.166 \\
Group & & & & \\
\hline
\end{tabular}

As can be seen in Table 7, the average scores of the control and experimental groups after carrying out the didactic interventions have increased considerably with respect to the pre-test scores. Specifically, the control group obtained an average score of 6.84 points with a standard deviation of 1.90 and a standard error of the mean of 0.20 points. The experimental group obtained an average score of 7.00 points with a standard deviation of 1.55 and a standard error of the mean of 0.16 points. These results suggest that both didactic methodologies favor the immediate learning of optics contents, and Hypothesis 1 can be accepted. (Hypothesis 1: "Students who use hyper-realistic simulations and STEM experiences to learn basic optics concepts related to light and color have similar average initial scores to students who follow an academic-expositional teaching intervention.") However, to check for statistically significant differences between the two groups, inferential statistical analysis was carried out. After verifying that the distributions were normal, a Student's t-test for independent samples was performed, the results of which are shown in Table 8.

Table 8. Student's t-test for independent samples of post-test I (CG vs. EG).

\begin{tabular}{cccccccc}
\hline & $\mathbf{t}$ & df & $\begin{array}{c}\text { Sig. } \\
\text { (Two-tailed) }\end{array}$ & $\begin{array}{c}\text { Mean } \\
\text { Difference }\end{array}$ & $\begin{array}{c}\text { Std. Error } \\
\text { Difference }\end{array}$ & \multicolumn{2}{c}{$\begin{array}{c}\text { 95\% Confidence Interval of } \\
\text { the Difference }\end{array}$} \\
\hline Post-test I & -0.208 & 171 & 0.836 & -0.05485 & 0.26422 & -0.57640 & -0.576402 \\
\hline
\end{tabular}

As can be seen in Table 8, the significance obtained (Sig. $=0.836$ ) allows us to affirm that there are no statistically significant differences between the two groups, as the difference in means between the post-test I was 0.054 points out of 10 . These results allow us to accept 
Hypothesis 2 proposed in the research, as it has been proven that the study groups show a similar level of learning after the interventions. (Hypothesis 2: "There are no statistically significant differences in the short-term knowledge level variable of students who follow a didactic intervention based on the use of hyper-realistic simulations and STEM experiences compared to students who follow an academic-expositional didactic intervention.")

To validate the didactic efficacy of the methodologies used over time, post-test II was used several months after the interventions to check whether the learning achieved by the students in both groups remained the same over time. The results obtained in post-test II in each working group, control and experimental, are shown below. Table 9 presents the descriptive statistics for the control and experimental groups in post-test II.

Table 9. Descriptive statistics of the average scores on post-test II (CG vs. EG).

\begin{tabular}{ccccc}
\hline Group & N & Mean & Std. Deviation & Std. Error Mean \\
\hline Control Group & 86 & 5.75 & 1.263 & 0.136 \\
Experimental & 87 & 6.98 & 1.517 & 0.163 \\
Group & & & & \\
\hline
\end{tabular}

As shown in Table 9, the control group obtains an average score of 5.75 points with a standard deviation of 1.26 and a standard error of the mean of 0.13 . However, the experimental group obtains an average score of 6.98 points with a standard deviation of 1.51 and a standard error of the mean of 0.16 points. With these data, it could be accepted that the STEM methodology applied with the experimental group has facilitated, to a greater extent, the learning of the contents in the long term. However, to verify the existence of statistically significant differences between groups, an inferential analysis was carried out using Levene's test and Student's t-test. Beforehand, we checked whether the distribution of the results for the two groups could be considered normal. Table 10 shows the results of the Student's t-test for independent samples.

Table 10. Student's t-test for independent samples of post-test II (CG vs. EG).

\begin{tabular}{|c|c|c|c|c|c|c|c|}
\hline & \multirow[t]{2}{*}{$\mathbf{t}$} & \multirow[t]{2}{*}{ df } & \multirow{2}{*}{$\begin{array}{l}\text { Sig. } \\
\text { (Two-tailed) }\end{array}$} & \multirow{2}{*}{$\begin{array}{c}\text { Mean } \\
\text { Difference }\end{array}$} & \multirow{2}{*}{$\begin{array}{l}\text { Std. Error } \\
\text { Difference }\end{array}$} & \multicolumn{2}{|c|}{$\begin{array}{l}95 \% \text { Confidence Interval of } \\
\text { the Difference }\end{array}$} \\
\hline & & & & & & Lower & Upper \\
\hline Post-test II & -5.763 & 171 & 0.000 * & -1.22711 & 0.21294 & -1.64746 & -1.7464 \\
\hline
\end{tabular}

The significance value obtained shown in Table 10 was lower than the reference value (Sig. <0.05). This allows us to affirm that there are statistically significant differences between the average grades obtained by the experimental group and the control group, with the learning done by the students in the experimental group being superior. These results coincide with those found in [97], which confirmed the importance of using STEM methodologies in the primary school classroom to achieve significant and long-term learning of the STEM contents worked on in the classroom. Likewise, the data allow us to accept Hypothesis 3 raised in the study. (Hypothesis 3: "There are statistically significant differences in the long-term learning variable between students in the experimental group using STEM simulations and experiences and students in the control group following an academic-expositional teaching intervention.")

Once the differences in results between the control group and the experimental group in each of the tests (inter-group differences) have been compared, it is necessary to analyze whether there are intra-group differences. In other words, we will study how the scores of each group have evolved over time to estimate whether the change has been significant and thus be able to assess the validity of the didactic interventions carried out in each group. Table 11 shows the descriptive statistics of paired samples of the control group. 
Table 11. Statistics of paired samples of the control group.

\begin{tabular}{cccccc}
\hline & & Mean & N & Std. Deviation & Std. Error Mean \\
\hline Pre-test vs. & Pre-test & 4.64 & 86 & 0.994 & 0.107 \\
Post-test I & Post-test I & 6.94 & 86 & 1.907 & 0.205 \\
\hline Pre-test vs. & Pre-test & 4.64 & 86 & 0.994 & 0.107 \\
Post-test II & Post-test II & 5.75 & 86 & 1.263 & 0.136 \\
\hline Post-test I vs. & Post-test I & 6.94 & 86 & 1.907 & 0.205 \\
Post-test II & Post-test II & 5.75 & 86 & 1.263 & 0.136 \\
\hline
\end{tabular}

Table 12 shows the paired samples t-test for the comparison of means between the three tests in the control group. The results shown in Table 12 indicate that the significance obtained is less than 0.05 in the three pairs analyzed, which indicates statistically significant differences between the average scores obtained by the control group in the three assessment instruments. Based on these results, we can affirm that the implementation of the didactic methodology carried out in the control group has been effective but only in the short term. Although the students in the control group significantly improve their initial scores immediately after the didactic intervention, this increase in scores is not maintained over time, as it decreases significantly between post-test I and post-test II.

Table 12. Paired samples test of the control group.

\begin{tabular}{|c|c|c|c|c|c|c|c|c|}
\hline & \multirow[t]{2}{*}{ Mean } & \multirow{2}{*}{$\begin{array}{c}\text { Std. } \\
\text { Deviation }\end{array}$} & \multirow{2}{*}{$\begin{array}{l}\text { Std. Error } \\
\text { Mean }\end{array}$} & \multicolumn{2}{|c|}{$\begin{array}{c}95 \% \text { Confidence Interval } \\
\text { of the Difference }\end{array}$} & \multirow[t]{2}{*}{$\mathbf{t}$} & \multirow[t]{2}{*}{ df } & \multirow{2}{*}{$\begin{array}{c}\text { Sig. } \\
\text { (Two-Tailed) }\end{array}$} \\
\hline & & & & Lower & Upper & & & \\
\hline Pre-Post I & -2.3071 & 2.16158 & 0.23309 & -2.770 & -1.8437 & -9.89 & 85 & 0.000 * \\
\hline Pre-Post II & -1.1161 & 1.42214 & 0.15335 & -1.421 & -0.8112 & -7.27 & 85 & 0.000 * \\
\hline $\begin{array}{l}\text { Post I-Post } \\
\text { II }\end{array}$ & 1.1910 & 2.40716 & 0.25957 & 0.6749 & 1.7071 & 4.589 & 85 & 0.000 * \\
\hline
\end{tabular}

* Sig. $<0.05$.

Subsequently, the results obtained with the experimental sample are shown. Table 13 shows the paired descriptive statistics for the experimental group.

Table 13. Statistics of paired samples of the experimental group.

\begin{tabular}{cccccc}
\hline & & Mean & N & Std. Deviation & Std. Error Mean \\
\hline Pre-test vs. & Pre-test & 4.43 & 87 & 0.953 & 0.102 \\
Post-test I & Post-test I & 7.00 & 87 & 1.551 & 0.166 \\
\hline Pre-test vs. & Pre-test & 4.45 & 86 & 0.921 & 0.099 \\
Post-test II & Post-test II & 6.98 & 86 & 1.517 & 0.163 \\
\hline Post-test I vs. & Post-test I & 6.97 & 86 & 1.543 & 0.166 \\
Post-test II & Post-test II & 6.98 & 86 & 1.517 & 0.163 \\
\hline
\end{tabular}

Table 14 shows the paired samples t-test for the comparison of the means between the three tests for this group of students. Table 14 shows that the significance is lower than 0.05 in the pre-test vs. post-test I pair and in the pre-test vs. post-test II pair, and, therefore, the differences between the scores of these instruments are statistically significant. However, the significance in the post-test I vs. post-test II pair is greater than the reference value 0.05 (Sig. $=0.981$ ), and, therefore, no statistically significant differences were found in the experimental group between the scores obtained in post-test I and the scores obtained in post-test II. Based on these results, we can affirm that the implementation of the didactic 
methodology carried out in the experimental group was effective beyond the short term. Students in the experimental group significantly improved their initial scores after the didactic intervention, and this increase in scores does not decrease significantly over time.

Table 14. Paired samples test of the experimental group.

\begin{tabular}{|c|c|c|c|c|c|c|c|c|}
\hline & \multirow[t]{2}{*}{ Mean } & \multirow{2}{*}{$\begin{array}{c}\text { Std. } \\
\text { Deviation }\end{array}$} & \multirow{2}{*}{$\begin{array}{l}\text { Std. Error } \\
\text { Mean }\end{array}$} & \multicolumn{2}{|c|}{$\begin{array}{c}95 \% \text { Confidence Interval } \\
\text { of the Difference }\end{array}$} & \multirow[t]{2}{*}{$\mathbf{t}$} & \multirow[t]{2}{*}{ df } & \multirow{2}{*}{$\begin{array}{c}\text { Sig. } \\
\text { (Two-Tailed) }\end{array}$} \\
\hline & & & & Lower & Upper & & & \\
\hline Pre-Post I & -2.5730 & 1.87165 & 0.20066 & -2.971 & -2.17410 & -12.823 & 86 & 0.000 * \\
\hline Pre-Post II & -2.5259 & 1.70125 & 0.18345 & -2.890 & -2.16120 & -13.769 & 85 & 0.000 * \\
\hline $\begin{array}{l}\text { Post I-Post } \\
\text { II }\end{array}$ & -0.0055 & 2.13176 & 0.22987 & -0.462 & 0.45147 & -0.024 & 85 & 0.981 \\
\hline
\end{tabular}

* Sig. $<0.05$.

Based on the results obtained in the inferential statistical analysis in both control and experimental groups, we can indicate that the students in the control group seem to have forgotten the concepts worked on over time, with the emergence of misconceptions about them akin to those obtained in the pre-test. This suggests that the control group has learned by rote the contents worked on in the didactic sessions. On the other hand, the students in the experimental group continued to remember the concepts after the passage of time, which indicates that they learned them meaningfully, as opposed to the control group. Therefore, we can accept Hypothesis 4. (Hypothesis 4: "Hyper-realistic simulations and STEM experiences on light and color facilitate meaningful, long-term learning for trainee primary school teachers.")

In view of the above results, it can be assumed that active learning methodologies lead to a remarkable increase in the conceptual understanding of physics [98,99], reproducing the scientific process in the classroom and aiding in the development of reasoning skills [100]. The findings confirm that STEM education, as a discipline-integrated educational approach, generates significant changes in students' academic performance [101] and the findings also emphasize the power of hands-on STEM activities in improving the scientific literacy of future teachers but also enhancing the professional competence of teachers to adopt integrated approaches in their teaching [101].

\subsection{Results for the Level of Teacher Self-Efficacy Variable}

In primary education, the teaching of these subjects, such as physics, is affected both by the negative attitudes and emotions of trainee teachers $[18,102,103]$ and by their low level of scientific preparation. These two variables (low levels of scientific knowledge and negative emotions) may influence the self-efficacy of future teachers. Therefore, this section shows the results obtained in the self-efficacy variable with the purpose of contrasting Hypothesis 5 formulated in the study and analyzing whether the implementation of the didactic interventions developed influenced the level of self-efficacy of the trainee teachers.

Table 15 shows the positive and negative levels of teacher self-efficacy before and after the intervention for the items of the self-efficacy questionnaire (specified in the section on measuring instruments). In the positive values, the percentage of students who selected the options "2: Fairly competent" and "3: Fully competent" are grouped together. Likewise, the percentage of students who selected the options "0: Not at all competent" and "1: Not very competent" were grouped into the negative values. 
Table 15. Positive and negative levels in percentages (\%) of teacher self-efficacy before and after teaching interventions.

\begin{tabular}{|c|c|c|c|c|}
\hline & \multicolumn{2}{|c|}{ Positive Value } & \multicolumn{2}{|c|}{ Negative Value } \\
\hline & Pre-Test & Post-Test & Pre-Test & Post-Test \\
\hline I1 & 34.7 & 85.5 & 65.3 & 14.5 \\
\hline $\mathrm{I} 2$ & 30.6 & 78.0 & 69.4 & 22.0 \\
\hline I3 & 17.9 & 71.7 & 82.1 & 28.3 \\
\hline $\mathrm{I} 4$ & 33.5 & 83.2 & 66.5 & 16.8 \\
\hline I5 & 35.3 & 78.0 & 64.7 & 22.0 \\
\hline I6 & 57.8 & 74.6 & 42.2 & 25.4 \\
\hline I7 & 69.4 & 92.5 & 30.6 & 7.5 \\
\hline I8 & 43.9 & 83.8 & 56.1 & 16.2 \\
\hline I9 & 44.5 & 60.1 & 55.5 & 39.9 \\
\hline $\mathrm{I} 10$ & 23.1 & 42.8 & 76.9 & 57.2 \\
\hline $\mathrm{I} 11$ & 22.0 & 56.6 & 78.0 & 43.4 \\
\hline $\mathrm{I} 12$ & 36.4 & 65.3 & 63.6 & 34.7 \\
\hline $\mathrm{I} 13$ & 31.2 & 70.5 & 68.8 & 29.5 \\
\hline $\mathrm{I} 14$ & 39.9 & 75.7 & 60.1 & 24.3 \\
\hline $\mathrm{I} 15$ & 41.6 & 74.0 & 58.4 & 26.0 \\
\hline I16 & 73.4 & 96.5 & 26.6 & 3.5 \\
\hline I17 & 53.8 & 92.5 & 46.2 & 7.5 \\
\hline $\mathrm{I} 18$ & 78.0 & 96.0 & 22.0 & 4.0 \\
\hline I19 & 76.3 & 98.3 & 23.7 & 1.7 \\
\hline $\mathrm{I} 20$ & 13.9 & 69.4 & 86.1 & 30.6 \\
\hline I21 & 15.0 & 75.1 & 85.0 & 24.9 \\
\hline I22 & 40.5 & 74.6 & 59.5 & 25.4 \\
\hline $\mathrm{I} 23$ & 37.6 & 65.3 & 62.4 & 34.7 \\
\hline $\mathrm{I} 24$ & 38.2 & 70.5 & 61.8 & 29.5 \\
\hline $\mathrm{I} 25$ & 41.0 & 75.1 & 59.0 & 24.9 \\
\hline I26 & 24.9 & 85.5 & 75.1 & 14.5 \\
\hline $\mathrm{I} 27$ & 43.9 & 80.9 & 56.1 & 19.1 \\
\hline $\mathrm{I} 28$ & 33.5 & 78.0 & 66.5 & 22.0 \\
\hline
\end{tabular}

As can be seen in Table 15, after the intervention, students had higher values for the variable of teaching self-efficacy in all the positive items that made up the teaching self-efficacy questionnaire. Similarly, a decrease in the percentage of students with low levels of teaching self-efficacy after the intervention can be observed in Table 15. Specifically, self-efficacy values improved notably for statements such as I1, "Explain the phenomenon of reflection of light," going from $34.7 \%$ in the pre-test to an improvement of $85.5 \%$ in the post-test. Likewise, 17, "Explain the concept of primary and secondary colors," increased from $69.4 \%$ in the pre-test to $92.5 \%$ in the post-test in reference to increased self-efficacy or positive value. Additionally, I17, "Explain what type of lens can be used to correct myopia, hyperopia, or astigmatism," improved notably in relation to the positive value, increasing from $53.8 \%$ to $92.5 \%$ in the positive value, and decreased notably in the negative value from $46.2 \%$ to $7.5 \%$. On the other hand, there was also an improvement in the level of teacher self-efficacy in teaching the procedural content of optics. For example, I26, "Design and develop a computer simulation to help the student understand these concepts," increased from $24.9 \%$ to $85.5 \%$ in the positive value and decreased from $75.1 \%$ to $14.5 \%$ in the negative value. In addition, along these lines, I28, "Perform a recreational physics exercise to explain these concepts to the students," increased from $33.5 \%$ positive to $78.0 \%$ positive in teaching self-efficacy, representing a promising improvement in teaching self-efficacy in relation to complex optics concepts.

There is a consensus in several research studies that trainee teachers' beliefs are often projected onto their future teaching in the primary classroom [104,105]. In primary education, the teaching of subjects such as physics is affected both by the low levels of competence shown by trainee teachers and by the poor scientific preparation of this group $[18,103]$. 
However, the above results are in line with other studies that conclude that experimental activity not only motivates and improves the future teacher's levels of scientific knowledge [106] but also increases the perception of teaching self-efficacy in science, technology, and mathematics, thus coinciding with previous studies [107-109]. Based on the above results, we can accept Hypothesis 5 proposed in this research. (Hypothesis 5: "The development and implementation of didactic interventions on basic concepts of optics related to light and color produces a positive evolution in the variable level of teaching self-efficacy in trainee teachers.")

\section{Discussion and Conclusions}

First, a summary of the hypotheses formulated and their implications for the research is shown in Table 16.

Table 16. Summary of hypothesis testing.

\begin{tabular}{|c|c|c|}
\hline Hypothesis & Accepted or Rejected? & Research Implications \\
\hline $\begin{array}{l}\text { Hypothesis } \mathbf{1} \text { (H1). } \\
\text { Students who use hyper-realistic simulations } \\
\text { and STEM experiences to learn basic optics } \\
\text { concepts related to light and color have } \\
\text { similar average initial scores to students who } \\
\text { follow an academic-expositional teaching } \\
\text { intervention. } \\
\text { Hypothesis } \mathbf{2} \text { (H2). } \\
\text { There are no statistically significant } \\
\text { differences in the short-term knowledge level } \\
\text { variable of students who follow a didactic } \\
\text { intervention based on the use of } \\
\text { hyper-realistic simulations and STEM } \\
\text { experiences compared to students who follow } \\
\text { an academic-expositional didactic } \\
\text { intervention. }\end{array}$ & Accepted & $\begin{array}{l}\text { It has been confirmed that both the use of } \\
\text { traditional methodologies and active } \\
\text { methodologies (didactic intervention } \\
\text { based on the use of hyper-realistic } \\
\text { simulations and STEM experiences) } \\
\text { promote short-term learning of the } \\
\text { contents, obtaining similar values in the } \\
\text { level of knowledge variable. }\end{array}$ \\
\hline
\end{tabular}

\section{Hypothesis 3 (H3).}

There are statistically significant differences in the long-term learning variable between students in the experimental group using STEM simulations and experiences and students in the control group following an academic-expositional teaching

intervention.

\section{Hypothesis 4 (H4).}

Hyper-realistic simulations and STEM experiences on light and color facilitate meaningful, long-term learning for trainee primary school teachers.

\section{Hypothesis 5 (H5).}

The development and implementation of didactic interventions on basic concepts of optics related to light and color produces a positive evolution in the variable level of teaching self-efficacy in trainee teachers.
}

Accepted

Accepted

The use of hyper-realistic simulations and the STEM experiences designed promote the acquisition of scientific competence in the trainee teacher, combating the preconceptions found in trainees and significantly increasing the long-term learning of optics compared to more traditional teaching.

Regarding the achievement of Specific Objectives 1 and 2, related to the cognitive domain, the descriptive and inferential statistical analysis of the data obtained has revealed an improvement in the cognitive domain of the trainee teachers in the process of teaching the scientific concepts under study. However, depending on the methodology used in the different didactic interventions, we can affirm that the students in the experimental group, who worked with hyper-realistic simulations and STEM experiences, assimilated the knowledge in a more satisfactory way, achieving significant learning. Specifically, their 
learning has lasted over time, and the misconceptions found in the pre-test have been combated with the intervention developed. However, the students in the control group, who used a more traditional methodology in their teaching process, forgot over time the contents learned, and some of the misconceptions found at the beginning of the research have resurfaced in them. This implies that the learning of the selected scientific concepts of light and color by means of a traditional methodology was short-term and probably more rote than that of the pupils in the experimental group. We consider these results to be proof of the didactic validity of the resources used in the experimental group when carrying out teaching interventions on optics concepts.

In addition, regarding the achievement of Specific Objective 3, related to the teaching self-efficacy variable, a positive evolution has been observed in the participants' levels of teaching self-efficacy. As some studies [52] point out, levels of teacher self-efficacy in science are raised when positive experiences with science teaching occur. Specifically, student participants have been found to improve their levels of teacher self-efficacy following the development and implementation of teaching interventions. These results seem to indicate that future primary school teachers feel more competent to teach optics concepts to their future students, which may improve the future teaching of these concepts from the early stages of school. These results are in line with the statements of other authors $[104,105]$ who indicated that trainee teachers' beliefs are often projected onto their future teaching in the primary classroom. If a teacher feels unprepared to teach science, this will contribute to fostering negative attitudes towards science learning in future students [86]. Additionally, based on the results obtained in the research with respect to the didactic interventions developed, we can conclude that the use of hyper-realistic simulations and the STEM experiences designed promote the acquisition of scientific competence in the trainee teacher combats the misconceptions found in them and significantly increases the learning of optics with respect to more traditional teaching. These results are in line with those obtained in other studies [74], where it was found that students who used hyper-realistic simulations to study optics concepts learned more than students who used schematic simulations and students who used the traditional laboratory. Similarly, other authors [110] report that students using simulations obtained better results than those using real equipment. We therefore consider it relevant to carry out these type of activities and workshops with trainee teachers so that they can increase their levels of teaching self-efficacy, thus favoring their future professional development.

The results obtained show that the practical activities prove to be an effective tool for the promotion of the teachers' scientific-experimental didactics [57] and the learning levels of this group. Initially, insufficient content management was observed, but the use of STEM didactic tools with the experimental participant sample led to a considerable increase in the level of learning about optics and, consequently, an improvement in the scientific literacy of this group, which is necessary to better teach science. Primary school teachers must have a strong mastery of basic physics and physical science because of their influence as future teachers on many students [111]. In this sense, we believe that teacher preparation based on science-based teaching is essential to ensure student learning. Teachers need to know the content to reconstruct, adapt, restructure, and simplify it to make it comprehensible to students [112]. Therefore, we agree with other studies [113] on the importance of the practical experimental approach in the physics teaching-learning process to improve the scientific preparation of teachers in these areas and to show them ways to transform scientific-technological content into didactic representations and use them in practice.

On the other hand, we consider that, although subject knowledge is indispensable, it does not in itself generate ideas of how to present particular content to students. A didactic knowledge of the content is required for a good teacher [114,115]. Three fundamental aspects in the development of didactic content knowledge [116] are content knowledge, teaching practice, and emotional attributes. The affective domain is closely linked to teaching competence $[117,118]$ since, as many authors [119] maintain, trainee teachers who 
show high self-efficacy in teaching physics and chemistry have higher positive emotions and lower negative emotions towards teaching these subjects than those with low selfefficacy. In this sense, the results obtained in this study on the self-efficacy variable suggest that the use of teaching strategies that favor positive emotional states leads to an increase in feelings of competence and personal efficacy, thus coinciding with the contributions of [120]. Teachers' beliefs and attitudes regarding classroom management, discipline, behavioral control, and an effective learning environment can and should be modified, as these changes play a determining role in effective teaching [121]. Accordingly, teaching teachers to become more self-effective should be a prerequisite in teacher training courses. High levels of teacher competence contribute to improving teachers' abilities to manage personal and contextual resources linked to quality learning. Therefore, the teachers also improve students' motivation and academic performance [122,123].

Additionally, teachers with good self-efficacy tend to be more confident in applying active teaching methodologies that focus on students and their learning. That is, selfeffective teachers are open to innovation and are also eager to use new methods and strategies in teaching [124]. To be successful in the study of science, and physics in particular, it is very important to recreate interesting, challenging, and fun learning situations that allow students' active participation in the activities, facilitate interaction with invisible and multidimensional objects, reinforce theoretical concepts, and provide experiences related to real applications [125]. In this sense, we agree with [126] that illustrating the phenomena of optics by means of experiments made with homemade or low-cost materials allows each student to construct his or her own learning. Therefore, it is assumed that this research presents several effective didactic possibilities for learning optics in active learning contexts. However, implementing an experimental didactic proposal requires, in addition to the design of the prototypes and experiments, an instructional guide to support the teacher and the student to ensure the cognitive link of the programmed learning with the live experience of the phenomenon [57].

Teaching physics involves building bridges between scientific knowledge and students' previously constructed ideas. To do this, the teacher must rework scientific knowledge so that students can use it to interpret and transform their environment and encourage them to construct congruent models of scientific learning [127]. Therefore, for future teachers to be able to explain and make predictions about a variety of physical phenomena, they should be trained through different methodologies that foster students' interest and motivation [127]. More effective science teaching requires teachers to be comfortable with the discourse, to believe in their ability to teach it, and to want to do so [128]. Therefore, it is necessary to emphasize the basic competences that a teacher must have to conduct quality teachinglearning processes [129]. The process of becoming a teacher is a long succession of stages in which the future professional is trained to teach as effectively as possible and to enter a profession that has always been classified as vocational [130]. However, today's society demands new challenges regarding the initial training of future teachers so that, focusing on students, they are trained using active methodologies [131,132]. Along these lines, including the interdisciplinary teaching of STEM areas in curricula will help educators to understand scientific-technological disciplines as entities interconnected with life [133]. Moreover, with this educational model, teachers are not only experts in a single subject but also have the additional responsibility of guiding their students in all STEM subjects [71]. Consequently, this will entail the reorganization of teacher education programs in universities [101], as STEM education requires teachers to excel in the appropriate use of knowledge, skills, and attitudes towards scientific-technological disciplines [133].

Author Contributions: Conceptualization, all authors; methodology, all authors; software, F.L.N.-C.; validation, all authors; formal analysis, F.L.N.-C. and G.M.-B.; investigation, all authors; resources all authors; data curation, F.L.N.-C. and G.M.-B.; writing-original draft preparation, all authors; writing-review and editing, all authors; visualization, all authors; supervision, all authors; project administration, G.M.-B.; funding acquisition, G.M.-B. All authors have read and agreed to the published version of the manuscript. 
Funding: Grant GR21047 funded by Junta de Extremadura and by "ERDF A way of making Europe". Project PID2020-115214RB-I00 funded by MCIN/AEI/ 10.13039/501100011033.

Institutional Review Board Statement: This is a non-interventional study. All participants were informed about their assured anonymity, about why the research was being conducted and how their data were going to be used. According to Spanish legislation (Organic Law 15/1999), no further ethical approval is required.

Informed Consent Statement: Informed consent was obtained from all subjects involved in the study.

Conflicts of Interest: The authors declare no conflict of interest. The funders had no role in the design of the study; in the collection, analyses, or interpretation of data; in the writing of the manuscript; or in the decision to publish the results.

\section{References}

1. Jenkins, E.W.; Pell, G. The Relevance of Science Education Project (ROSE) in England: A Summary of Findings; Centre for Studies in Science and Mathematics Education: Leeds, UK, 2006.

2. Rocard, M.; Csermely, P.; Jorde, D.; Lenzen, D.; Walwerg-Henriksson, H.; Hemmo, V. Science Education Now: A Renewed Pedagogy for the Future of Europe; European Commission Community Research: Brussels, Belgium, 2007.

3. Beauchamp, G.; Parkinson, J. Pupils' attitudes towards school science as they transfer from an ICT-rich primary school to a secondary school with fewer ICT resources: Does ICT matter? Educ. Inf. Tech. 2008, 13, 103-118. [CrossRef]

4. Murphy, C.; Beggs, J. Children perceptions of school science. Sch. Sci. Rev. 2003, 84, 109-116.

5. Osborne, J.; Simon, S.; Collins, S. Attitudes towards science: A review of the literature and its implications. Int. J. Sci. Educ. 2003, 25, 1049-1079. [CrossRef]

6. Ramsden, J.M. Mission impossible? Can anything be done about attitudes to science? Int. J. Sci. Educ. 1998, 20, 125-137. [CrossRef]

7. Parkinson, J.; Hendley, D.; Tanner, H.; Stables, A. Pupils' attitudes to science in key stage 3 of the National Curriculum: A study of pupils in South Wales. Res. Sci. Tech. Educ. 1998, 16, 165-176. [CrossRef]

8. Dávila, M.A. Las emociones y sus causas en el aprendizaje de Física y Química, en el alumnado de Educación Secundaria. REUrEDC 2017, 14, 570-586.

9. Vázquez, A.; Manassero, M.A. El declive de las actitudes hacia la ciencia de los estudiantes: Un indicador inquietante para la educacion cientifica. REurEDC 2008, 5, 274-292. [CrossRef]

10. Fuentes, M.; González, J. Necesidades formativas del profesorado de Secundaria para la implementación de experiencias gamificadas en STEM. Rev. Educ. Dist. 2017, 17, 54.

11. González-Tirado, R.M.; González-Maura, V. Diagnóstico de necesidades y estrategias de formación docente en las universidades. Rev. Iber. Educ. 2007, 43, 6.

12. UNESCO. ICT Competency Standards for Teachers: Competency Standards Modules; UNESCO: Paris, France, 2008. Available online: http:/ / portal.unesco.org/ci/en/ev.php-URL_ID=25731\&URL_DO=DO_TOPIC\&URL_SECTION=201.html (accessed on 1 March 2022).

13. Campos, J.A. La Formación del Profesorado Novel en la Universidad de Barcelona; ICE-Octaedro: Barcelona, Spain, 2012.

14. Bozu, Z.; Imbernon, F. La profesión docente en momentos de cambios. ¿Qué nos dicen los estudios internacionales? Profesorado. Rev. Curríc. Form. Prof. 2016, 20, 467-492.

15. Martínez, G.; Cañada, F.; Naranjo, F.L.; Dávila, M.A. Autorreflexión de emociones sentidas en el laboratorio de física para mejorar la competencia científica de maestros en formación. In La Enseñanza de las Ciencias en el Actual Contexto Educativo; Membiela, P., Casado, N., Cebreiros, M.I., Vidal, M., Eds.; Educación Editora: Ourense, Spain, 2017; pp. 181-185.

16. Van Zee, E.H.; Hammer, D.; Bell, M.; Roy, P.; Peter, J. Learning and teaching science as inquiry: A case study of elementary school teachers' investigations of light. Sci. Educ. 2005, 89, 1007-1042. [CrossRef]

17. Guisasola, J.; Morentin, M. ¿Comprenden la naturaleza de la ciencia los futuros maestros y maestras de Educación Primaria? Rev. Electr. Ens. Cienc. 2007, 6, 246-262.

18. Mellado, V.; Borrachero, A.B.; Brígido, M.; Melo, L.V.; Dávila, M.A.; Cañada, F.; Conde, M.C.; Costillo, E.; Cubero, J.; Esteban, R.; et al. Las emociones en la ensenanza de las ciencias. Ensenanza Cienc. 2014, 32, 11-36.

19. Avraamidou, L. Prospective elementary teachers' science teaching orientations and experiences that impacted their development. Int. J. Sci. Educ. 2013, 35, 1698-1724. [CrossRef]

20. Mullis, I.V.S.; Jenkins, L.B. The Science Report Card: Elements of Risk and Recovery. Trends and Achievement Based on the 1986 National Assessment. In National Government Publication; Princeton, N.J., Ed.; Educational; Testing Service: Princeton, NJ, USA, 1988.

21. Appleton, K. Student teachers' confidence to teach science: Is more science knowledge necessary to improve self-confidence? Int. J. Sci. Educ. 1995, 17, 357-369. [CrossRef]

22. Westerback, M.E. Studies on attitude toward teaching science and anxiety about teaching science in preservice elementary teachers. J. Res. Sci. Teach. 1982, 19, 603-616. [CrossRef]

23. Tosun, T. The beliefs of preservice elementary teachers toward science and science teaching. Sch. Sci. Math. 2000, 100, 374-379. [CrossRef] 
24. Van Aalderen-Smeets, S.I.; Walma van der Molen, J.H.; Asma, L.J.F. Primary teachers' attitudes toward science: A new theoretical framework. Sci. Educ. 2012, 96, 158-182. [CrossRef]

25. Rennie, L.J.; Goodrum, D.; Hackling, M. Science teaching and learning in Australian schools: Results of a national study. Res. Sci. Educ. 2001, 31, 455-498. [CrossRef]

26. Jarvis, T.; Pell, A. Primary teachers' changing attitudes and cognition during a two-year science in-service programme and their effect on pupils. Int. J. Sci. Educ. 2004, 26, 1787-1811. [CrossRef]

27. Plonczak, I. Science for all: Empowering elementary school teachers. Educ. Citiz. Soc. Just. 2008, 3, 167-181. [CrossRef]

28. Van Driel, J.H.; Beijaard, D.; Verloop, N. Professional development and reform in science education: The role of teachers' practical knowledge. J. Res. Sci. Teach. 2001, 38, 137-158. [CrossRef]

29. Weinburgh, M. The effect of Tenebrio obscurus on elementary preservice teachers' content knowledge, attitudes, and self-efficacy. J. Sci. Teach. Educ. 2007, 18, 801-815. [CrossRef]

30. Haney, J.J.; Czerniak, C.M.; Lumpe, A.T. Teacher beliefs and intentions regarding the implementation of science education reform strands. J. Res. Sci. Teach. 1996, 33, 971-993. [CrossRef]

31. Tobin, K.; Tippins, D.J.; Gallard, A.J. Research on instructional strategies for teaching science. In Handbook of Research on Science Teaching and Learning; Gabel, D., Ed.; MacMillan Publishing Company: New York, NY, USA, 1994; pp. 45-93.

32. Abell, S.K.; Roth, M. Constraints to teaching elementary science: A case study of a science enthusiast student teacher. Sci. Educ. 1992, 76, 581-595. [CrossRef]

33. Duit, R.; Schecker, H.; Höttecke, D.; Niedderer, H. Teaching Physics. In Handbook of Research on Science Education; Lederman, N.G., Abell, S.K., Eds.; Routledge: New York, NY, USA, 2014; Volume 2, pp. 434-456.

34. Harding, J. Science in a masculine strait-jacket. In Gender, Science and Mathematics; Parker, L.H., Rennie, L., Fraser, B., Eds.; Springer Science \& Business Media: Perth, Australia, 1996; Volume 2, pp. 3-15.

35. Andersson, B.; Kärrqvist, C. How Swedish pupils, aged 12-15 years, understand light and its properties. Eur. J. Sci. Educ. 1983, 5, 387-402. [CrossRef]

36. Colin, P.; Chauvet, F.; Viennot, L. Reading images in optics: Students' difficulties and teachers views. Int. J. Sci. Educ. 2002, 24, 313-332. [CrossRef]

37. Osborne, J.F.; Black, P.; Meadows, J.; Smith, M. Young children's (7-11) ideas about light and their development. Int. J. Sci. Educ. 1993, 15, 83-93. [CrossRef]

38. Tural, G. Active learning environment with lenses in geometric optics. Asia-Pac. Forum Sci. Learn. Teach. 2015, 16, 1-18.

39. Uzun, S.; Alev, N.; Karal, I.S. A cross-age study of an understanding of light and sight concepts in physics. Sci. Educ. Int. 2013, 24, 129-149.

40. Kaltakci-Gurel, D.; Eryilmaz, A.; McDermott, L.C. Identifying pre-service physics teachers' misconceptions and conceptual difficulties about geometrical optics. Europ. J. Phys. 2016, 37, 045705. [CrossRef]

41. Özcan, Ö. Investigating students' mental models about the nature of light in different contexts. Eur. J. Phys. 2015, 36, 65042. [CrossRef]

42. Heywood, D. Primary Trainee Teachers' Learning and Teaching About Light: Some pedagogic implications for initial teacher training. Int. J. Sci. Educ. 2005, 27, 1447-1475. [CrossRef]

43. Goldberg, F.M.; McDermott, L.C. Student difficulties in understanding image formation by a plane mirror. Phys. Teach. 1986, 24, 472-481. [CrossRef]

44. Feher, E.; Rice, K. A comparison of teacher-student conceptions in optics. In Proceedings of the Second International Seminar: Misconceptions and Educational Strategies in Science and Mathematics; Novak, J.D., Ed.; Cornell University Press: Ithaca, NY, USA, 1987; pp. 108-117.

45. Huang, H.-W.; Hwang, B.-T. Students' conceptual developments on shadow formation and their relations to formal and concrete operation stages. Proc. Natl. Sci. Counc. Prob. China Part D Math. Sci. Technol. Educ. 1992, 2, 27-38.

46. Abd-El-Khalick, F.; Lederman, N.G. Improving science teachers' conceptions of nature of science: A critical review of the literature. Int. J. Sci. Educ. 2000, 22, 665-701. [CrossRef]

47. Bhattacharyya, S.; Volk, T.; Lumpe, A. Influence of an Extensive Inquiry-Based Field Experience on Pre-Service Elementary Student Teachers' Science Teaching Beliefs. J. Sci. Teach. Educ. 2009, 20, 199-218. [CrossRef]

48. Czerniak, C.M.; Schriver, M.L. An examination of preservice science teachers' beliefs and behaviors as related to self-efficacy. $J$. Sci. Teach. Educ. 1994, 5, 77-86. [CrossRef]

49. King, K.; Shumow, L.; Lietz, S. Science education in an urban elementary school: Case studies of teacher beliefs and classroom practices. Sci. Educ. 2001, 85, 89-110. [CrossRef]

50. Bandura, A. Self-efficacy mechanism in human agency. Am. Psych. 1982, 37, 122. [CrossRef]

51. Watters, J.J.; Ginns, I.S.; Neumann, P.; Schweitzer, R. Enhancing Preservice Teacher Education Students' Sense of Science Teaching Self Efficacy. In Australian Teacher Education Association; Australian Teacher Education Association: Brisbane, Australia, $1994 ;$ p. 28.

52. Ramey-Gassert, L.; Shroyer, M.G.; Staver, J.R. A qualitative study of factors influencing science teaching self-efficacy of elementary level teachers. Sci. Educ. 1996, 80, 283-315. [CrossRef]

53. Grossman, P.L. The Making of a Teacher: Teacher Knowledge and Teacher Education; Teachers College Press: New York, NY, USA, 1990.

54. Angelini, M.L.; García-Carbonell, A. Percepciones sobre la Integración de Modelos Pedagógicos en la Formación del Profesorado: La Simulación y Juego y el Flipped Classroom. EKS 2015, 16, 16-30. [CrossRef] 
55. Molas, N.; Rosselló, M. Revolución en las aulas: Llegan los profesores del siglo XXI. La introducción de las TIC en las aulas y el nuevo rol docente. DIM 2010, 19, 1-9.

56. Dávila, M.A.; Borrachero, A.B.; Cañada, F.; Martínez, G.; Sánchez, J. Evolución de las emociones que experimentan los estudiantes del grado de maestro en educación primaria, en didáctica de la materia y la energía. REurEDC 2015, 12, 550-564. [CrossRef]

57. Lozada, E.P.; Falcón, N. Diseño de prototipos experimentales orientados al aprendizaje de la óptica. REurEDC 2009, 6, 452-465.

58. UNESCO. Manual de Entrenamiento, Aprendizaje Activo de Óptica y Fotónica. Aprendizaje Active en Óptica; UNESCO: Paris, France, 2006.

59. Rivero, H. Cómo Mejorar mi Clase de Física Nivel Superior; Editorial Trillas: Tlaxcala, Mexico, 2004.

60. Kapucu, S. Guided Inquiry-based electricity experiments: Pre-service elementary science teachers' difficulties. J. Educ. Future 2016, 10, 71-93.

61. Banerjee, A. Teaching science using guided inquiry as the central theme: A professional development model for high school science teachers. Sci. Educat. 2010, 19, 1-9.

62. Liang, L.L.; Richardson, G.M. Enhancing prospective teachers' science teaching efficacy beliefs through scaffolded, studentdirected inquiry. J. Elem. Sci. Educ. 2009, 21, 51-66. [CrossRef]

63. Gil, D. Contribución de la historia y de la filosofía de las ciencias al desarrollo de un modelo de enseñanza-aprendizaje como investigación. Ens. Cienc. 1993, 11, 197-212.

64. Díaz-Barriga, F. Aportaciones de las perspectivas constructivista y reflexiva en la formación docente en el bachillerato. Perf. Educ. 2002, 24, 6-25.

65. García, P.; Angulo, F. Un modelo didáctico para la formación inicial del profesorado de Ciencias. Rev. Interuniv. Form. Prof. 2003, $17,37-49$

66. National Research Council. STEM Learning Is Everywhere: Summary of a Convocation on Building Learning Systems; National Academies Press: Washington, DC, USA, 2014.

67. Furner, J.M.; Kumar, D.D. The mathematics and science integration argument: A stand for teacher education. EURASIA J. Math. Sci. Tech. Educ. 2007, 3, 185-189. [CrossRef]

68. Stohlmann, M.; Moore, T.J.; Roehrig, G.H. Considerations for teaching integrated STEM education. J-PEER. 2012, 2, 4. [CrossRef]

69. Von Garnier, C. La Metamorfosis Necesaria en la Escuela; Ituci siglo XXI: Sevilla, Spain, 2010.

70. Riskowski, J.L.; Todd, C.D.; Wee, B.; Dark, M.; Harbor, J. Exploring the Effectiveness of an Interdisciplinary Water Resources Engineering Module in an Eighth Grade Science Course. Int. J. Eng. Educ. 2009, 25, 181-195.

71. Sanders, M.E. STEM, STEM education, STEMmania. Tech. Teach. 2008, 68, 20-26.

72. Crismond, D.P.; Adams, R.S. The informed design teaching and learning matrix. J. Eng. Educ. 2012, 101, 738-797. [CrossRef]

73. Borrego, M.; Henderson, C. Increasing the use of evidence-based teaching in STEM higher education: A comparison of eight change strategies. J. Eng. Educ. 2014, 103, 220-252.

74. Martínez, G.; Naranjo, F.L.; Pérez, Á.L.; Suero, M.I.; Pardo, P.J. Comparative study of the effectiveness of three learning environments: Hyper-realistic virtual simulations, traditional schematic simulations and traditional laboratory. Phys. Educ. Res. 2011, 7, 20111. [CrossRef]

75. Martínez, G.; Naranjo, F.L.; Pérez, Á.L.; Suero, M.I.; Pardo, P.J. Use of computer generated hyper-realistic images on optics teaching: The case study of an optical system formed by two opposed parabolic mirrors. J. Sci. Educ. 2013, 14, 25-29.

76. Martínez, G.; Naranjo, F.L.; Pérez, Á.L.; Suero, M.I. Development of hyperrealistic simulations to teach concepts about colors. Color Res. Appl. 2016, 41, 330-332. [CrossRef]

77. Naranjo, F.L.; Martínez, G.; Pérez, Á.L.; Pardo, P.J.; Suero, M.I. Teaching rainbows with simulations: Revisiting Minnaert's lab experiment. Appl. Opt. 2017, 56, G54-G69.

78. Naranjo, F.L.; Martínez, G.; Pérez, Á.L.; Pardo, P.J.; Suero, M.I. Spectral simulations for the teaching of metamer color pairs at various educational levels. Óptica. Pura Y Apl. 2018, 52, 4.

79. Martínez, G.; Pérez, Á.L.; Suero, M.I.; Pardo, P.J. Detection of misconceptions about color and an experimentally tested proposal to combat them. Int. J. Sci. Educ. 2013, 35, 1299-1324. [CrossRef]

80. Martínez, G.; Naranjo, F.L.; Mateos, M. Design and development of stem workshops to improve scientific/technological literacy in primary education. In Proceedings of the INTED 2018, Valencia, Spain, 5-7 March 2018; IATED, Ed.; IATED: Valencia, Spain, 2018; pp. 2433-2439.

81. POV-Ray. The Persistence of Vision Raytracer. 2018. Available online: http:/ /www.povray.org/ (accessed on 1 March 2022).

82. Courtial, J.; Nelson, J. Ray-optical negative refraction and pseudoscopic imaging with Dove-prism arrays. New J. Phys. 2008, 10, 23028. [CrossRef]

83. Danner, A.J. Photorealistic ray tracing aids understanding of metamaterials. SPIE Newsroom 2009. [CrossRef]

84. Dolling, G.; Wegener, M.; Linden, S.; Hormann, C. Photorealistic images of objects in effective negative-index materials. Opt. Express 2006, 14, 1842-1849. [CrossRef] [PubMed]

85. Naranjo, F.L.; Martínez, G.; Pérez, Á.L.; Suero, M.I.; Pardo-Fernández, P.J. A new online tool to detect color misconceptions. Color Res. Appl. 2016, 41, 325-329. [CrossRef]

86. Brígido, M.; Borrachero, A.B.; Bermejo, M.L.; Dávila, M.A. Programa de intervención para la mejora de las creencias de autoeficacia en las clases de ciencias. Int. J. Dev. Educ. Psychol. 2014, 5, 73-80. 
87. Martínez, G.; Naranjo, F.; Mateos, M. Análisis de las creencias de autoeficacia de docentes de Educación primaria en formación en la impartición de Contenidos curriculares de óptica. In Investigación, Innovación Docente y TIC. Nuevos Horizontes Educativos; Alonso, S., Romero, J.M., Rodríguez, C., Sola, J.M., Dykinson, S.L., Eds.; Dykinson: Madrid, Spain, 2019.

88. Ding, C.S.; Hershberger, S.L. Assessing content validity and content equivalence using structural equation modeling. Struc. Equ. Mod. 2002, 9, 283-297. [CrossRef]

89. Ding, L.; Chabay, R.; Sherwood, B.; Beichner, R. Evaluating an electricity and magnetism assessment tool: Brief electricity and magnetism assessment. Phys. Rev. Spec.-Top. Phys. Educ. Res. 2006, 2, 10105. [CrossRef]

90. McColgan, M.W.; Finn, R.A.; Broder, D.L.; Hassel, G.E. Assessing students' conceptual knowledge of electricity and magnetism. Phys. Rev. Phys. Educ. Res. 2017, 13, 20121. [CrossRef]

91. Ding, L.; Beichner, R. Approaches to data analysis of multiple-choice questions. Phys. Rev. Spec.-Top. Phys. Educ. Res. 2009, 5, 20103. [CrossRef]

92. Melo-Niño, L.V.; Sánchez, R.; Cañada, F.; Martínez, G. Learning difficulties on Archimedes' Principle in the floating context. Rev. Bras. Ens. Fís. 2016, 38, e4401.

93. Welch, S.; Comer, J. Quantitative Methods for Public Administration: Techniques and Applications. In Quantitative Methods for Public Administration: Techniques and Applications, 3rd ed.; Waveland Press Inc.: Long Grove, CA, USA, 2006.

94. George, D.; Mallery, P. IBM SPSS Statistics 23 Step by Step: A Simple Guide and Reference, 14th ed.; Routledge: Boston, MA, USA, 2016.

95. Perales, F.J.; Nievas, F. Ideas previas en óptica geométrica: Un estudio descriptivo. Rev. Invent. Esc. 1991, 13, 77-84.

96. Kaltakci-Gurel, D.; Eryilmaz, A.; McDermott, L.C. Development and application of a four-tier test to assess pre-service physics teachers' misconceptions about geometrical optics. Res. Sci. Tech. Educ. 2017, 35, 238-260. [CrossRef]

97. Mateos, M.; Martínez, G.; Naranjo, F.L. Learning Science in Primary Education with STEM Workshops: Analysis of Teaching Effectiveness from a Cognitive and Emotional Perspective. Sustainability 2020, 12, 3095. [CrossRef]

98. Sokoloff, D.; Thornton, R. Using Interactive Lecture Demostrations to create and active learnig environment. Phys. Teach. 1997, 35, 340-347. [CrossRef]

99. Laws, P. Calculus-based physics without lectures. Phys. Today 1991, 44, 24-31. [CrossRef]

100. Alborch, A.; Pandiella, S.; Benegas, J.; Aprendizaje Activo en Optica (Programa ALOP). Relato de una experiencia en la escuela secundaria. Anu. Dig. Invent. Educ. 2015. Available online: http://revistas.bibdigital.uccor.edu.ar/index.php/adiv/article/ view /3997 (accessed on 1 March 2022).

101. Kline, J.T. Integrative learning and interdisciplinary studies. Peer Rev. 2005, 7, 8-10.

102. Czerniak, C.M.; Chiarelott, L. Teacher education for effective science instruction-A social cognitive perspective. J. Teach. Educ. 1990, 41, 49-58. [CrossRef]

103. Kazempour, M. I Can't Teach Science! A Case Study of an Elementary Pre-Service Teacher's Intersection of Science Experiences, Beliefs, Attitude, and Self-Efficacy. Int. J. Environ. Sci. Educ. 2014, 9, 77-96.

104. Kazempour, M.; Sadler, T.D. Pre-service teachers' science beliefs, attitudes, and self-efficacy: A multi-case study. Teach. Educ. 2015, 26, 247-271. [CrossRef]

105. Ramey-Gassert, L.; Shroyer, M.G. Enhancing science teaching self-efficacy in preservice elementary teachers. J. Elem. Sci. Educ. 1992, 4, 26-34. [CrossRef]

106. Martínez, G.; Naranjo, F.L.; Mateos, M.; Sánchez, J. Recreational Experiences for Teaching Basic Scientific Concepts in Primary Education: The Case of Density and Pressure. Eurasia J. Math. Sci. Technol. Educ. 2018, 14, 1-16.

107. Duran, E.; Ballone-Duran, L. Project ASTER: A model staff development program and its impact on early childhood teachers' self-efficacy. J. Elem. Sci. Educ. 2005, 17, 1-12. [CrossRef]

108. Jimoyiannis, A. Designing and implementing an integrated technological pedagogical science knowledge framework for science teachers professional development. Comp. Educ. 2010, 55, 1259-1269. [CrossRef]

109. Martínez, G.; Mateos, M.; Naranjo, F.L. La didáctica de las áreas STEM en la formación del profesorado. Desarrollo de propuestas de intervención en el aula de educación secundaria. In La Enseñanza de las Ciencias Desde la Pedagogía Social. El Paradigma Educativo STEM Como Modelo Para Educación Integral Ingenieros y Ciudadanos; Feltrero, R., Ed.; Global Knowledge Academics: Madrid, Spain, 2020; pp. 141-153.

110. Finkelstein, N.D.; Adams, W.; Keller, C.J.; Kohl, P.B.; Perkins, K.K.; Podolefsky, N.S.; Reid, S.; LeMaster, R. When learning about the real world is better done virtually: A study of substituting computer simulations for laboratory equipment. Phys. Rev. Spec.-Top. Phys. Educ. Res. 2005, 1, 010103. [CrossRef]

111. Bolívar-Botia, A. Conocimiento didáctico del contenido y didácticas específicas. Prof. Rev. Curr. Form. Prof. 2011, 9, 1-39.

112. Marcelo, C. Formación del Profesorado Para el Cambio Educativo; PPU: Barcelona, Spain, 1994.

113. Alves-Filho, J.P.; Pietrocola, M.; Pinheiro, T.F. Nova transposição didática gera novas atividades experimentais. Enc. Pesq. Ens. Fís. 2000, 2, 76-155.

114. Shulman, L.S. Knowledge and Teaching: Foundations of the New Reform. Harv. Educ. Rev. 1987, 57, 1-22. [CrossRef]

115. Garritz, A.; Mellado, V. El conocimiento didáctico del contenido y la afectividad. In Conocimiento Didáctico del Contenido. Una perspectiva Iberoamericana; Garritz, A., Daza, S.F., Lorenzo, G., Eds.; Editorial Academia Española: Saarbrücken, Germany, 2014; pp. 229-264.

116. Kind, V. Pedagogical content knowledge in science education: Perspectives and potential for progress. Stud. Sci. Educ. 2009, 45, 169-204. [CrossRef] 
117. Salovey, P.; Woolery, A.; Mayer, J.D. Emotional intelligence: Conceptualization and measurement. In Blackwell Handbook of Social Psychology: Interpersonal Processes; Fletcher, G.J.O., Clark, M.S., Eds.; Blackwell Publisher: Malden, MA, USA, 2001 ; pp. $279-307$.

118. Prieto, L. Autoeficacia del Profesor Universitario: Eficacia Percibida y Práctica Docente; Narcea Ediciones: Madrid, Spain, 2007.

119. Brígido, M.; Borrachero, A.B.; Bermejo, M.L.; Mellado, V. Prospective primary teachers' self-efficacy and emotions in science teaching. Eur. J. Teach. Educ. 2013, 36, 200-217. [CrossRef]

120. Wolters, C.A.; Daugherty, S.G. Goals structures and teachers' sense of efficacy: Their relation and association to teaching experience and academic level. J. Educ. Psych. 2007, 99, 181-193. [CrossRef]

121. Martin, N.K.; Sass, D.A. Construct validation of the Behavior and Instructional Management Scale. Teach. Teach. Educ. 2010, 26, 1124-1135. [CrossRef]

122. Rodríguez, S.; Núñez, J.C.; Valle, A.; Blas, R.; Rosario, P. Autoeficacia docente, motivación del profesor y estrategias de enseñanza. Escr. Psico. 2009, 3, 1-7.

123. Gurcay, D. Preservice physics teachers' beliefs regarding their teacher efficacy and classroom management. Procedia-Soc. Behav. Sci. 2015, 197, 1101-1106. [CrossRef]

124. Saracaloğlu, A.S.; Yenıce, N. Investigating the self-efficacy beliefs of science and elementary teachers with respect to some variables. JTPE 2009, 5, 2.

125. Saprudin, S.; Liliasari, L.; Prihatmanto, A.S. Pre-Service Physics Teachers' Concept Mastery and the Challenges of Game Development on Physics Learning. J. Phys. 2017, 895, 012109. [CrossRef]

126. Monasterio, R. Óptica Experimental con Materiales Casero o de Bajo Costo. Conferencia Interamericana Sobre Educación en Física; Universidad Simón Bolívar: Caracas, Venezuela, 2001.

127. Jaime, E.A.; Escudero, C. El trabajo experimental como posible generador de conocimiento en enseñanza de la física. Ens. Cienc. 2011, 29, 371-380.

128. Park, S.; Oliver, J.S. Revisiting the conceptualisation of Pedagogical Content Knowledge (PCK): PCK as a conceptual tool to understand teachers as professionals. Res. Sci. Educ. 2008, 38, 261-284. [CrossRef]

129. Vaillant, D. Mejorando la formación y el desarrollo profesional docente en Latinoamérica. Rev. Pens. Educ. 2007, 41, 207-222.

130. Day, C.; Gu, Q. Profesores: Vidas Nuevas, Verdades Antiguas; Narcea Ediciones: Madrid, Spain, 2012.

131. Zaragoza-Casterad, J.; Generelo-Lanaspa, E.; Julián-Clemente, J.A. Innovación docente en el marco universitario: Una experiencia en el contexto de la formación inicial del maestro especialista en Educación Física. REIFOP 2008, 8, 1-9.

132. Tejada, J. Profesionalización docente en la universidad: Implicaciones desde la formación. RUSC 2013, 10, 170-184.

133. Corlu, M.S.; Capraro, R.M.; Capraro, M.M. Introducing STEM education: Implications for educating our teachers in the age of innovation. Eğitim Ve Bilim 2014, 39, 74-85. 